\title{
Properties and structure of the seasonal snow cover in the continental regions of China
}

\author{
Wei Wenshou, ${ }^{1,2}$ Qin Dahe, ${ }^{1}$ Liu Mingzhe ${ }^{2}$ \\ ${ }^{1}$ Cold and Arid Regions Environmental and Engineering Research Institute, Chinese Academy of Sciences, Lanzhou, Gansu 730000, China \\ ${ }^{2}$ Xinjiang Institute of Ecology and Geography, Chinese Academy of Sciences, Ürümqi, Xinjiang 830011, China
}

\begin{abstract}
The continental regions of China are extensively covered by snow during winter. In this paper, the seasonal snow cover in the Tien Shan and Altay mountains is observed and analyzed, based on the characteristics of the dry-cold snow cover accumulating under the continental climatic conditions in northwest China. Compared with the humid-warm snow cover, the dry-cold snow cover is characterized mainly by small density, low water content, large temperature gradient, thick depth hoar, etc., and its metamorphism is dominated by the thermal exchange and the pressure of the overlying snow layers. According to the observed data, the solar radiation flux on the snow surface is dominated by a negative balance in the arid areas in China during the snow season; the albedo on the new-fallensnow surface is up to $96 \%$, and the transmission depth of shortwave radiation in dry-cold snow cover is $28 \mathrm{~cm}$. During the snowmelt season in spring, the thickness of the depth hoar can occupy $80 \%$ of the whole snow cover.
\end{abstract}

\section{GEOGRAPHICAL SURVEY AND SNOW-GOVER DISTRIBUTION}

Because of the peculiar structure of the mountains and basins in the continental regions of China, a region with humidwarm climate is separated from a region with dry-cold climate. The continental and maritime climates form in different regions. Thus, distribution of different types of snow covers (i.e. dry-cold vs humid-warm snow cover) is one of the main features of the regional climatic difference in China.

The area of snow-cover distribution during winter in China is $9.0 \times 10^{6} \mathrm{~km}^{2}$, and its scope is closely related to latitude, elevation and natural conditions of the underlying surface. The area covered by stable snow is $4.2 \times 10^{6} \mathrm{~km}^{2}$ ( $\mathrm{Li}$ and $\mathrm{Mi}$, 1983), and is mainly distributed in the Tibetan (QinghaiXizang) Plateau, Xinjiang, northeast China and Inner Mongolia. In these regions, the duration of the snow cover is $>90$ days per year, and the maximum depths are all $>1.00 \mathrm{~m}$, $1.52 \mathrm{~m}$ in the Yili river watershed and $2.30 \mathrm{~m}$ in the eastern part of the Nianqing Tanggula mountains and Nielamu region in Xizang. The properties, i.e. structure and metamorphism, of the snow cover are different in different regions of China due to the differences of the regional climate and vapour sources. The snow cover accumulating under the maritime climatic conditions in northeast and southwest China belongs to a humid-warm type, and that accumulating under the continental climatic conditions in northwest China belongs to a dry-cold type. Compared with the maritime snow cover, the properties of the continental snow cover are characterized mainly by small density, large temperature gradient within snow, low water content, restrained growth of intercrystallines between the snow grains ( $\mathrm{Ma}$ and $\mathrm{Hu}, 1990$ ), low-strength, well-developed depth hoar, and frequent occurrence of wet whole-depth avalanches in the mountainous areas during the snowmelt season in spring. Based on the regional characteristics of the snow cover in northwest China, this paper discusses mainly the properties and structure of the seasonal snow cover in the arid continental regions, especially in north Xinjiang.

\section{PROPERTIES AND STRUGTURE OF DRY-COLD SNOW COVER}

\subsection{Snow accumulation and temperature gradient within the snow cover}

In the continental regions of China, the accumulation period of the seasonal snow cover is generally from mid-October to mid-March. The snow-cover thickness increases with increasing elevation, but the maximum depth occurs in a zone 1700$2200 \mathrm{~m}$ a.s.l; then it thins again with increasing elevation. The snow-cover thickness is $0.30-0.60 \mathrm{~m}$ in the plains and hilly regions and $0.50-0.90 \mathrm{~m}$ in the mountainous regions, with a maximum and multi-year average of $1.52 \mathrm{~m}$ (1997) and $0.87 \mathrm{~m}$, respectively, at the Tien Shan Station for Snow and Avalanche Research (1776 m a.s.l.). In the zone above the snowline (3800-4000 $\mathrm{m}$ a.s.l.) or in the glacial areas, winter snowfall forms only $6 \%$ of the annual precipitation. In the area of Ürümqi Glacier No. $1\left(43^{\circ} 06^{\prime} \mathrm{N}, 87^{\circ} 15^{\prime} \mathrm{E}\right.$; $4050 \mathrm{~m}$ a.s.l.; $1.84 \mathrm{~km}^{2}$ ) at the headwater of Ürümqi River in the Tien Shan, for example, the annual precipitation is $432 \mathrm{~mm}$, but the precipitation during the period October-March is only $26 \mathrm{~mm}$. In the plains and mid-mountain zones, winter snowfall contributes $19 \%$ of the annual precipitation in the areas covered by a stable snow cover. At the Tien Shan Station for Snow and Avalanche Research, for example, the annual precipitation is $842 \mathrm{~mm}$, and the snowfall during the winter period of the snow accumulation is $189 \mathrm{~mm}$, or $23 \%$ of the annual precipitation. According to the statistical climatic data, the maximum snow-cover depth occurs in the con- 

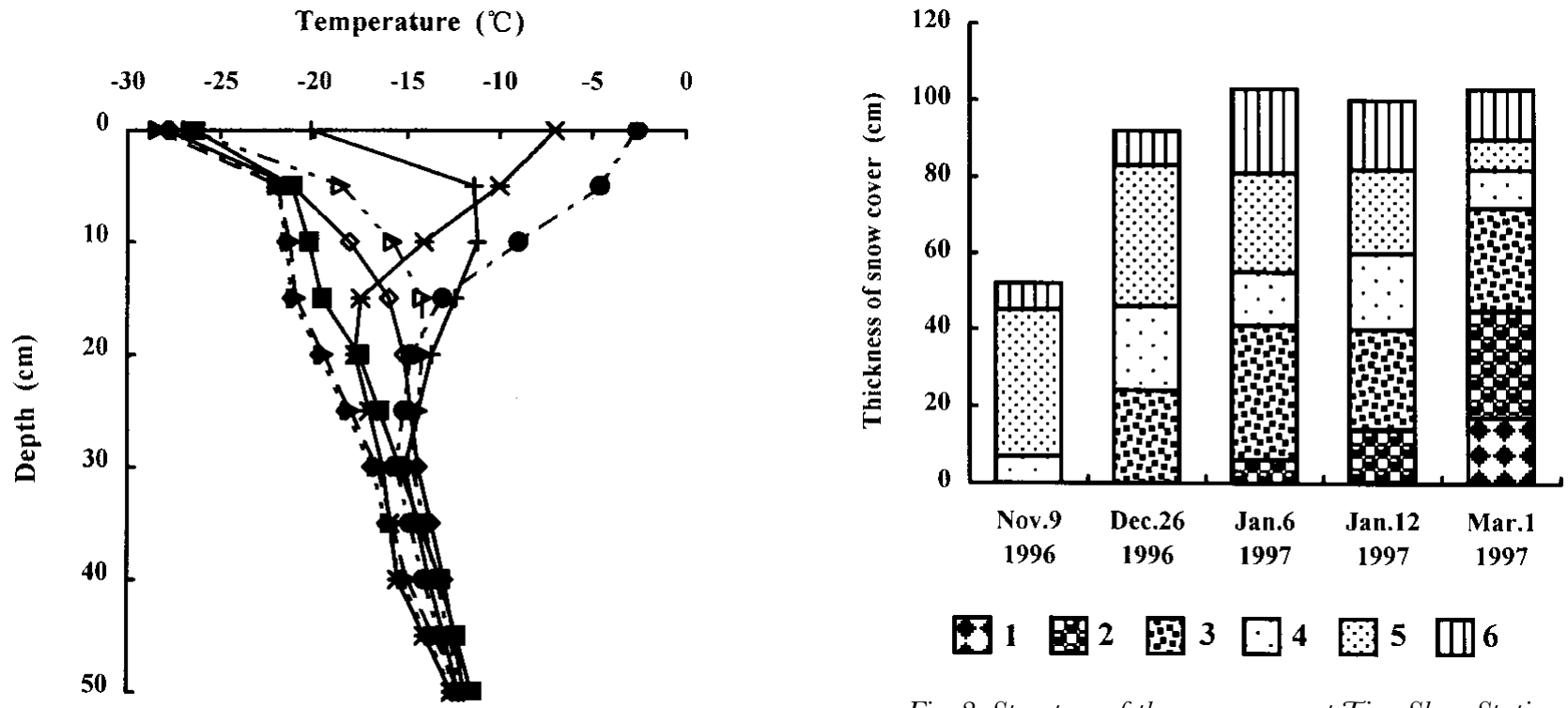

\begin{abstract}
Fig. 2. Structure of the snow cover at Tien Shan Station for Snow and Avalanche Research: (1) cemented depth hoar; (2) depth hoar; (3) coarse-grained snow; (4) mid-grained snow; (5) fine-grained snow; (6) new-fallen snow.
\end{abstract}

Fig. 1. Temperature distribution with depth within the snow cover in the area of Tien Shan Station for Snow and Avalanche Research (1776 m a.s.l.), 12 January 1997.

tinental regions in late January. The monthly air temperature is lowest in January, and it is $-14.0^{\circ} \mathrm{C}$ in north Xinjiang.

Controlled by low temperature in the arid continental regions, subsidence of new-fallen snow is firstly affected by the overburden pressure of the overlying snow layer. The snow is compacted with the thickness increase of the overlying snow layers. Secondly, the subsidence of new-fallen snow is affected by the thermal exchange and sublimation-recondensation processes. The negative temperature gradient within the snow cover reaches the maximum value when the air temperature drops to the lowest point in January (Fig. 1). According to observations at the Tien Shan Station for Snow and Avalanche Research, the mean temperature gradient within the snow cover is $-0.28^{\circ} \mathrm{C} \mathrm{cm}^{-1}$, and the maximum is $-0.56^{\circ} \mathrm{C} \mathrm{cm}^{-1}$. The daily variation of the negative temperature gradient within the dry-cold snow cover in the Tien Shan can penetrate $>0.20 \mathrm{~m}$ below the snow surface, whereas that in the San Juan Mountains, Colorado, U.S.A., does not exceed $0.15 \mathrm{~m}$. This large difference between the two regions is caused by the different climatic conditions. During a severe winter, the effect of the temperature gradient within the snow cover in the continental regions makes the snow grains recrystallize during the sublimation-recondensation of the thermal exchange (Wei and Ma, 1990). In the snowmelt season in spring, the air temperature increases, the snow surface receives more solar radiation, the surface snow begins to melt and the melting water permeates downward and makes the snow temperature rise. The temperature gradient within the snow cover still exists due to the diurnal-nocturnal temperature difference. Along with the climate-warming and increased melting as well as the increase in ground temperature, the bottom snow begins to melt and a boundary of $0^{\circ} \mathrm{C}$ occurs within the snow cover. The volume of permeating meltwater increases continuously and saturates the snow layer completely, the temperature of the whole snow cover tends to $0^{\circ}$ and the temperature gradient within the snow cover is sharply reduced.

\title{
2.2. Snow density and grain-size
}

The densities of snow accumulating under different climatic and regional conditions are significantly different; in northwest China, for example, they are quite different from those in Wilkes Land, Antarctica (Qin, 1995a), Canada and the northern U.S.A. (Bilello, 1967) and southwest China. The average snow-cover densities in northwest and southeast China vary within the ranges $0.20-0.23$ and $0.28-0.30$ $\mathrm{kg} \mathrm{m}^{-3}$, respectively. In the continental regions in northwest China, the monthly air temperature fluctuates within the range $-12^{\circ}$ to $-16^{\circ} \mathrm{C}$ in mid-winter, and the density of newfallen snow varies within the range $0.04-0.10 \mathrm{~kg} \mathrm{~m}^{-3}$ when the relative humidity is $70 \%$. Moreover, new-fallen-snow density varies linearly with deposition time, and the densification rate is $4.0 \times 10^{-3} \mathrm{~kg} \mathrm{~m}^{-3} \mathrm{~d}^{-1}$. The monthly air temperature fluctuates within the range $-2^{\circ}$ to $-6^{\circ} \mathrm{C}$ in southwest China during the same period, and the new-fallen snow density varies within the range $0.07-0.12 \mathrm{~kg} \mathrm{~m}^{-3}$. Densification of new-fallen snow is extremely rapid within the first 2 days after snowfall, and the densification rate reaches $5.5 \times 10^{-2} \mathrm{~kg} \mathrm{~m}^{-3} \mathrm{~d}^{-1}$. In the arid continental regions in northwest China, the water-vapor content shifts from the snow layers with high temperature to the snow layers with low temperature due to the temperature gradient within the snow cover. Thus, sublimation from the warmer snow grains and recondensation to the colder ones occurs, and the snow crystal structure changes. According to observations at the snow park of the Tien Shan Station for Snow and Avalanche Research, depth hoar forms at the bottom of the snow cover in mid-December (Wei, 1992), and the granular structure of the snow cover from bottom to top is in a sequence of depth hoar, coarse-grained snow, mid-grained snow, finegrained snow and new-fallen snow (or surface hoar). The thickness of the loose, coarse depth hoar increases with increasing snow-cover thickness, as does the negative temperature gradient within the snow cover. The depth-hoar thickness occupies $66 \%$ and $80 \%$ of the whole snow-cover depth in early February and early March (Fig. 2), respectively. Analogous results of snow-density data collected from Lake 


\begin{tabular}{|c|c|c|c|c|c|c|}
\hline \multirow{3}{*}{ Snow type } & \multirow[b]{2}{*}{ Snow grain-size } & \multirow[b]{2}{*}{ Tien Shan } & \multicolumn{2}{|r|}{ Snow density } & \multirow[b]{2}{*}{ Kazakhstan } & \multirow[b]{2}{*}{ Japan } \\
\hline & & & Baimangxue mountain & South Pole & & \\
\hline & $\mathrm{mm}$ & $\mathrm{kg} \mathrm{m}^{-3}$ & $\mathrm{~kg} \mathrm{~m}^{-3}$ & $\mathrm{~kg} \mathrm{~m}^{-3}$ & $\mathrm{~kg} \mathrm{~m}^{-3}$ & $\mathrm{~kg} \mathrm{~m}^{-3}$ \\
\hline New-fallen snow & $<0.5$ & $0.04-0.10$ & $0.07-0.119$ & & $0.04-0.12$ & $0.1-0.2$ \\
\hline Fine-grained snow & $0.5-1.0$ & $0.10-0.20$ & $0.14-0.35$ & $0.27-0.36$ & $0.14-0.23$ & $0.2-0.5$ \\
\hline Mid-grained snow & $1.0-2.0$ & $0.15-0.24$ & $0.18-0.39$ & $0.28-0.35$ & & \\
\hline Coarse-grained snow & $2.0-3.0$ & $0.19-0.28$ & $0.22-0.49$ & $0.26-0.36$ & $0.21-0.30$ & \\
\hline Depth hoar & $3.0-5.0$ & $0.21-0.30$ & $0.24-0.49$ & $0.25-0.35$ & $0.27-0.45$ & $0.3-0.5$ \\
\hline Cemented depth hoar & $3.0-6.0$ & $0.21-0.36$ & $0.0-0.56$ & & & \\
\hline
\end{tabular}

Biwa, Japan (Fujino, 1983), the South Pole (Qin, 1995b), the Chimkrak Avalanche Station, Kazakhstan (Xie and Severskiy, 1996), Baimangxue mountain, southwest China (Wang, 1992), and the Tien Shan Station for Snow and Avalanche Research are shown in Table 1 for comparison. The results show that the depth-hoar density in the Tien Shan is close to that at the South Pole, $9 \%$ larger than that at the Chimkrak Avalanche Station, and the density of the dry-cold snow cover is about $33 \%$ smaller than in other places, although the size of the snow grains is similar.

\subsection{Water content in the dry-cold snow cover and solar radiation}

New-fallen snow deposits in an environment with low temperature are dry, so the water content of the snow cover is low: $<1 \%, 3-5 \%$ and $8-11 \%$ when daily air temperatures are below $-16^{\circ} \mathrm{C}$, above $-10^{\circ} \mathrm{C}$ and about $-3^{\circ} \mathrm{C}$ in mid-January, mid-February and mid- or late March, respectively. According to observations at Baimangxue mountain, the snow-cover water content is $>10 \%$ when the daily air temperature is $-6^{\circ} \mathrm{C}$ in January. Therefore, the low-temperature environment is the main cause of the low water content of the dry-cold snow cover in the arid continental regions in China.

The radiation flux on the surface of the dry-cold snow cover in the arid continental regions in China is dominated by a negative value (i.e. heat flux is into the atmosphere) from November to early March, and its lowest value is $-186 \mathrm{~W} \mathrm{~m}^{-2}$ in January (Wei and others, 1996). The daily radiation tends to balance out with the increase of the sun's altitude; the wholedepth melting of the seasonal snow cover occurs in late March (Table 2), and the radiation flux becomes positive in mid- or late April, although the snow cover does not completely melt out at that time. The transmissive intensity of short-wave radiation is strong in the dry-cold snow cover. The parameters observed at the Tien Shan Station for Snow and Avalanche Research, using the EKO 0.3-3.0 $\mu$ m short- wave radiometer on two individual fine days, are shown in Table 2. The results show that the lower the water content of the snow cover is, the stronger the transmissive intensity of shortwave radiation will be, which can be verified by the temperature gradient within snow cover at $1600 \mathrm{~h}$ in Figure 1.

The observations showed that the albedo of new-fallen snow was $82 \%, 96 \%, 90 \%$ and $78 \%$ on 3 December 1995 , 1 January, 21 February and 27 March 1996, respectively. The reflectivity on the surface of new-fallen snow, observed on the surface of Ürümqi Glacier No. 1 on 23 July 1995, was $64 \%$. These results show that the lower the air temperature and water content of the snow cover are, the stronger the reflected radiation will be.

\section{GONGLUSIONS}

The seasonal snow cover in the arid continental and cold regions in China reflects the basic features of the snow cover that accumulates under continental climatic conditions. Compared with the snow cover accumulating under maritime climatic conditions in Japan, the Antarctic and southwest China, the properties of snow cover in the arid continental regions and cold regions in China have the following characteristics:

(1) The negative temperature gradient within the seasonal snow cover is large, and the metamorphism of the snow is dominated by sublimation-recondensation under thermal exchange conditions and by the pressure of overlying snow layers. Therefore, the accumulation of the snow layers with the different grain-sizes has a certain regularity, and the deposition is in a sequence of new-fallen snow (or surface hoar), fine-grained snow, mid-grained snow, coarse-grained snow and depth hoar from the top to the bottom; snow density increases with increasing grain-size, but is smaller than that with the same grain-size in the humid-warm regions. Depth hoar

Table 2. Observed parameters of the transmissive intensity of shortwave radiation at Tien Shan Station for Snow and Avalanche Research, 1997

\begin{tabular}{|c|c|c|c|c|c|c|c|c|c|}
\hline \multirow{3}{*}{ Time } & \multirow{3}{*}{$\begin{array}{c}\text { Air temperature } \\
{ }^{\circ} \mathrm{C}\end{array}$} & \multirow{3}{*}{$\begin{array}{c}\text { Air humidity } \\
\%\end{array}$} & \multirow{3}{*}{$\begin{array}{c}\text { Radiation } \\
\text { balance } \\
\mathrm{W} \mathrm{m}{ }^{-2}\end{array}$} & \multirow{3}{*}{$\begin{array}{c}\text { Snow-cover } \\
\text { water content } \\
\%\end{array}$} & \multicolumn{5}{|c|}{ Absorptivity of thermal flux at different depths in snow cover } \\
\hline & & & & & $5 \mathrm{~cm}$ & $10 \mathrm{~cm}$ & $20 \mathrm{~cm}$ & $25 \mathrm{~cm}$ & $28 \mathrm{~cm}$ \\
\hline & & & & & $\%$ & $\%$ & $\%$ & $\%$ & $\%$ \\
\hline 1100 h, 1 January & -19.2 & 72 & -86 & $<1$ & 48.3 & 71.3 & 92.2 & 95.7 & 98.6 \\
\hline 1200 h, 23 March & -2.9 & 78 & 193 & 6 & 51.6 & 87.1 & 96.5 & 99.0 & \\
\hline
\end{tabular}


develops strongly, and its thickness can occupy about $80 \%$ of the whole thickness of snow cover up to the snowmelt season.

(2) The water content of the snow cover is low during the snow-accumulation period, the surface hoar forms in mid-winter and the evaporation from the snow surface is negative.

(3) Reflectivity on the new-fallen-snow surface is extremely high due to the effect of the continental climate and the peculiar properties and structure of the snow cover; the transmissive intensity of shortwave radiation is strong in the dry-cold snow cover because the water content of the snow cover is low.

\section{ACKNOWLEDGEMENTS}

The study was supported by the National Natural Science Foundation of China (49871004) and by the third state of Basic Research on the Dynamic Change of the Cryosphere of the Chinese Academy of Sciences.

\section{REFERENCES}

Bilello, M. A. 1967. Relationships between climate and regional variations in snow-cover density in North America. In Öura, H., ed. Physics of snow and ice. Vol. 1, Part 2. Sapporo, Hokkaido University. Institute of Low
Temperature Science, 1015-1028.

Fujino, Y. 1983. [Snow of Lake Biwa.] In [An introduction to limnology of Lake Biwa]. Kyoto, Institute of Lake Biwa Research, 79-83. [In Japanese.]

Li Peiji and Mi Desheng. 1983. [Distribution of snow cover in China.] 7. Glaciol. Geocryol., 5(4), 9-18. [In Chinese.]

Ma Weilin and Hu Ruji. 1990. Relationship between the development of depth hoar and avalanche release in the Tian Shan mountains, China. 7. Glaciol., 36(122), 37-40.

Qin Dahe, ed. 1995a. Report on glaciological research of the 1990 International Trans-Antarctic Expedition (1989-1994).] Beijing, Science Press. Chinese Academy of Sciences. Lanzhou Institute of Glaciology and Geocryology. [In Chinese.]

Qin Dahe. 1995b. [A study of present climatic and environmental record in the surface snow of the Antarctic ice sheet.] In [The physical process in the shallow surface layer of the Antarctic ice sheet]. Beijing, Science Press. Chinese Academy of Sciences. Lanzhou Institute of Glaciology and Geocryology, 32-40. [In Chinese.]

Wang Yanlong. 1992. [Avalanche research in China.] In [Basic features of snow cover related to avalanche]. Beijing, Ocean Press, 19-44. [In Chinese.]

Wei Wenshou. 1992. Avalanches in the Tien Shan mountains, China. [Abstract.] Ann. Glaciol., 16, 140.

Wei Wenshou and Ma Weilin. 1990. [Analysis of the characteristics of development of depth hoar in the snow pack at west Tianshan mountains.] In [Fourth National Conference on Glaciology and Geocryology (Selection). Proceedings]. Beijing, Science Press, 243-249. [In Chinese.]

Wei Wenshou, Wang Cunniu and Jiang Fengqing. 1996. [Study on the processes of thermal exchange, evaporation and sublimation of the snow cover in the Tianshan mountains, China.] 7. Glaciol. Geocryol., Special Issue 18, 129-139. [In Chinese.]

Xie Zichu and I.V. Severskiy. 1996. [Snow and avalanche in Tianshan mountains.] In [Physical and mechanical characteristics of the snow cover]. Changsha, Hunan Teachers' University Press, 72-94. [In Chinese.] 